\title{
Pengaruh Penerapan Model Pembelajaran Kooperatif Tipe Teams Games Tournament terhadap Hasil Belajar Matematika Siswa
}

\author{
Alfi Yunita1*, Ratulani Juwita², dan Suci Elma Kartika ${ }^{3}$ \\ Program Studi Pendidikan Matematika, STKIP PGRI Sumatera Barat \\ Jalan Gn. Pangilun, Padang, Sumatera Barat, Indonesia \\ 1*alfiyunita@ymail.com
}

Artikel diterima: 25-10-2019, direvisi: 28-01-2020, diterbitkan: 31-01-2020

\begin{abstract}
Abstrak
Anggapan bahwa matematika sulit dan besarnya rasa takut siswa untuk bertanya pada guru menjadi permasalahan tersendiri dalam pembelajaran matematika. Solusinya adalah dengan menerapkan suatu model pembelajaran kooperatif seperti Tipe Teams Games Tournament (TGT). Penelitian ini bertujuan untuk mengetahui apakah terdapat pengaruh model pembelajaran kooperatif tipe Teams Games Tournament (TGT) terhadap hasil belajar siswa. Jenis penelitian adalah penelitian pre-eksperimen, dengan desain penelitian one shot case study. Populasi penelitian adalah seluruh siswa kelas VIII SMPN 5 Padang yang terdaftar pada tahun pelajaran 2019/2020 yang berjumlah sembilan kelas. Sampelnya yaitu 28 siswa kelas VIII.5 yang ditentukan dengan teknik purposive sampel. Instrumen yang digunakan adalah soal posttest berupa essay. Hasil penelitian ini adalah terdapat pengaruh model pembelajaran kooperatif tipe Teams Games Tournament (TGT) terhadap hasil belajar siswa. Siswa tampak aktif dengan melakukan banyak aktivitas belajar.

Kata kunci: Hasil Belajar, Pembelajaran kooperatif, Teams Games Tournament.
\end{abstract}

The Effect of Cooperative Learning Model Type Teams Games Tournament towards Student Learning Outcomes In Mathematics

\begin{abstract}
The assumption that mathematics is difficult and the fear of students asking teachers is a problem in learning mathematics. The solution is to apply a cooperative learning model such as the Teams Games Tournament (TGT). This study aims to determine whether there is an effect of the Implementation of the Teams Games Tournament (TGT) Cooperative Learning Model on the Learning Outcomes of Grade VIII Students of SMPN 5 Padang. This type of research is pre-experimental research, with a one-shot case study design. The study population was all eighth-grade students of SMPN 5 Padang who were enrolled in the 2019/2020 school year, totaling nine classes. The sample is 28 students of class VIII. 5 determined by a purposive sample technique. The instrument used was a post-test question in the form of an essay. Thus it can be concluded that there is an Effect of the Implementation of the Teams Games Tournament (TGT) Cooperative Learning Model Against Student Learning Outcomes.

Keywords: Learning Outcomes. Cooperative Learning, Teams Games Tournament.
\end{abstract}




\section{Pendahuluan}

Matematika sebagai ilmu dasar memegang peranan penting dalam membentuk pola pikir peserta didik (Haq, 2012; Yuhasriati, 2012). Hal ini disebabkan karena matematika memiliki struktur keterkaitan yang kuat dan jelas antara konsepnya sehingga matematika melatih untuk berpikir secara rasional. Tanpa matematika ilmu pengetahuan seperti biologi, fisika, kimia, bahkan ilmu sosial akan sulit diterapkan di lingkungan. Maka dari itu, matematika sangat penting dikuasai oleh siapapun dalam kehidupan (Afriansyah, 2014; Apiati, Heryani, \& Muslim, 2019). Hal ini yang menjadikan kedudukan matematika sangat penting dalam perkembangan ilmu pengetahuan dan teknologi. Menyadari arti tersebut maka hasil belajar khususnya materi pelajaran matematika perlu mendapat perhatian (Rahayu \& Afriansyah, 2014; Ma'ruf, Syafii, \& Kusuma, 2019).

Penguasaan matematika tidak terlepas dari ketercapaian tujuan hasil belajar yang diperolehnya. Ketercapaian tujuan pembelajaran matematika dapat dilihat berdasarkan keberhasilan dan ketuntasan hasil belajar matematika yang diperoleh siswa (Yasa \& Madio, 2014). Ketuntasan hasil belajar, berdasarkan Permendikbud No. 23 tahun 2016 berisi tentang Standar Penilaian Pendidikan yang berdasarkan Kriteria Ketuntasan Minimal (KKM) yang sudah ditentukan oleh satuan pendidikan. Oleh sebab itu, keberhasilan yang diperoleh siswa harus berdasarkan KKM yang telah ditentukan oleh satuan pendidikan (Nst \& Rahmi, 2017).

Hasil observasi tanggal 13 sampai dengan 15 Agustus 2019 di kelas VIII SMPN 5 Padang, terlihat siswa belum terlibat secara optimal. Siswa masih banyak diam saat guru meminta siswa untuk bertanya jika ada yang belum dipahami, bersedia diminta untuk kedepan kelas menjawab soal atau permasalahan yang diberikan hanya sebagian besarnya saja dan siswa yang lainnya hanya duduk diam dan menerima jawaban dari temannya yang tampil kedepan. Tidak ada usaha siswa untuk berdiskusi jika terdapat kendala dalam menjawab soal.

Melakukan wawancara kepada guru matematika sebanyak 2 orang, diperoleh informasi bahwa guru pernah menerapkan pembelajaran kelompok tapi hanya kelompok besar saja dan belum terlaksana sesuai harapan guru. Hal ini disebabkan siswa tidak mau bekerjasama dalam kelompok. Hanya siswa pandai saja yang mengerjakan latihan sedangkan siswa yang lainnya hanya menyalin jawaban yang telah didapat oleh siswa yang pandai.

Sementara itu, berdasarkan hasil wawancara siswa, mereka menganggap pelajaran matematika itu sulit. Siswa merasa mengantuk jika belajar matematika dikarenakan proses pembelajaran yang masih konvensional. Serta siswa masih merasa takut untuk bertanya karena tidak paham dengan apa yang dikerjakan.

Solusi dari permasalahan di atas, adalah dengan menerapkan suatu model pembelajaran kooperatif. Model pembelajaran koperatif merupakan salah satu model pembelajaran yang dapat membuat siswa bertanggung jawab, dan tertarik dalam mengikuti pelajaran matematika (Firdaus \& Afriansyah, 2016). Model pembelajaran kooperatif juga dapat meningkatkan kerjasama antara guru dan siswa sehingga siswa dapat memahami konsep matematika dengan baik (Supriatna \& Afriansyah, 2018). Hal ini sesuai dengan pendapat Luritawaty (2018) bahwa masalah pemahaman konsep 
matematika dapat diatasi dengan meningkatkan kerjasama antara pendidik dan peserta didik dalam proses pembelajaran.

Salah satu model pembelajaran kooperatif yang dipilih dalam penelitian ini adalah Teams Games Tournament (TGT). TGT merupakan salah satu model pembelajaran yang dapat dengan mudah diterapkan di dalam kelas oleh guru, dan siswa sebagai tutor sebaya yang dapat melibatkan aktivitas seluruh siswa yang heterogen (Yasa \& Madio, 2014). Selain itu, TGT juga mengandung unsur suatu permainan. Model pembelajaran ini dapat meningkatkan kinerja pengajaran guru dan prestasi belajar siswa, serta merupakan suatu kiat, petunjuk, strategi, dan seluruh proses yang dapat mempertajam pemahaman daya ingat, serta belajar sebagai proses yang menyenangkan dan bermakna (Afriansyah, 2016; Susanna, 2018)

Menurut Silberman, model belajar mengajar TGT yang dikembangkan oleh Robert Slavin, merupakan teknik pembelajaran dengan menggabungkan kelompok belajar dengan kompetisi tim, dan bisa digunakan untuk meningkatkan pembelajaran beragam fakta, konsep dan keterampilan (Widhiastuti \& Fachrurrozie, 2014). Artinya dengan menggunakan pembelajaran kooperatif tipe TGT diharapkan dapat memperbaiki hasil belajar siswa yang rendah. Hal ini dikarenakan dalam proses pembelajarannya, model pembelajaran ini menekankan kepada kerjasama antar kelompok untuk bekerja atau berdiskusi memahami informasi dan latihan sebelum kompetisi dengan kelompok lainnya dalam turnamen (Damayanti, S., Apriyanto, M. T., 2017).
Berdasarkan permasalahan yang telah diuraikan, maka dilakukanlah penelitian ini dengan tujuan untuk mengetahui pengaruh model pembelajaran kooperatif tipe Team Games Tournament (TGT) terhadap hasil belajar matematika siswa. Peneliti berharap bahwa model pembelajaran kooperatif tipe TGT ini dapat berpengaruh positif terhadap peserta didik.

\section{Metode}

Penelitian ini adalah penelitian Pre Experimental dengan one shot case study yang dilaksanakan di SMP Negeri 5 Padang Semester Ganjil Tahun Pelajaran 2019/2020. Penentuan sampel dilakukan dengan cara Purposive Sample yaitu siswa kelas VIII.5 SMP Negeri 5 Padang yang terdiri dari 28 orang siswa. Instrumen yang digunakan dalam penelitian ini adalah tes akhir yang berbentuk essay yang terdiri dari 10 soal. Sebelum soal digunakan, soal diuji cobakan disekolah yang sama dengan kelas yang berbeda yaitu kelas VIII-3. Setelah melakukan uji coba, nilai siswa tersebut diolah kemudian dicari tingkat kesukaran, daya pembeda, dan reabilitas soal untuk melihat soal dapat digunakan sebagai alat pengumpulan data.

Teknik analisis data yang yang digunakan adalah uji t-satu pihak. Rubrik yang digunakan dalam penelitian ini adalah rubrik holistic,

Tabel 1.

Rubrik Holistik

\begin{tabular}{clll}
\hline \multicolumn{1}{c}{0} & \multicolumn{1}{c}{$\mathbf{1}$} & \multicolumn{1}{c}{$\mathbf{2}$} & \multicolumn{1}{c}{3} \\
\hline Tidak ada & Jawaban & Jawaban & Jawaban \\
jawaban & tidak & sedikit & benar dan \\
& benar & kekurangan & $\begin{array}{l}\text { berkaitan } \\
\text { dengan }\end{array}$ \\
& dan tidak & dan & konsep \\
& ada & berkaitan & \\
& kaitan & dengan & \\
& dengan & konsep & \\
& konsep & & \\
& & &
\end{tabular}


karena penilaiannya dilakuakn secara keseluruhan dengan skala 4 (lihat tabel 1).

\section{Hasil dan Pembahasan}

Berdasarkan penelitian yang telah dilakukan tanggal 16 Januari 2019 sampai dengan tanggal 26 Januari 2019 diperoleh hasil belajar matematika siswa melalui tes akhir yang diberikan pada kelas sampel. Hasil perhitungan dapat dilihat pada tabel 2 .

Berdasarkan Tabel 2 terlihat bahwa nilai maksimum 99 dan nilai minimum 49 dengan rata-rata siswa 85,16 dan simpangan baku 12,71. Dilihat dari perolehan data di atas diketahui bahwa hasil belajar siswa meningkat yaitu lebih besar dari KKM sehingga sebaran nilai tertinggi siswa menyebar. Uji normalitas dapat dilihat pada Tabel 3.

Table 3 menunjukkan bahwa data hasil tes akhir berdistribusi normal sehingga diperoleh keputusan yaitu terima $H_{0}$ karena $L_{0}<$ $L_{\text {tabel }}$, karena data hasil tes akhir berdistribusi normal maka langkah selanjutnya melakukan uji t - satu pihak seperti terlihat pada tabel 4.

Tabel 4 menunjukkan hasil analisis data tes akhir uji $t$-satu pihak. Hasil uji $t$ diperoleh $t_{\text {hitung }}=5,57$ dan $\quad t_{\text {tabel }}=1,71$, karena

Tabel 2.

Nilai Tes Siswa Kelas Sampel

\begin{tabular}{ccccc}
\hline $\begin{array}{c}\text { Kelas } \\
\text { Sampel }\end{array}$ & $\overline{\boldsymbol{X}}$ & S & $\boldsymbol{X}_{\text {maks }}$ & $\boldsymbol{X}_{\text {min }}$ \\
\hline Eksperimen & 85,16 & 12,71 & 99 & 49
\end{tabular}

Tabel 3.

Analisis Uji Normalitas pada Data Hasil Tes Akhir

\begin{tabular}{rcccc}
\hline Data & $\boldsymbol{L}_{\boldsymbol{o}}$ & $\boldsymbol{L}_{\text {tabel }}$ & $\boldsymbol{\alpha}$ & Hasil \\
\hline Tes Akhir & 0,099 & 0,173 & 0,05 & Normal
\end{tabular}

Tabel 4.

Analisis Uji t-satu pihak pada data hasil tes akhir

\begin{tabular}{cccccc}
\hline Data & $\overline{\boldsymbol{x}}$ & $\boldsymbol{s}$ & $\boldsymbol{\alpha}$ & $\boldsymbol{t}_{\text {hitung }}$ & $\boldsymbol{t}_{\text {tabel }}$ \\
\hline Tes & 85,16 & 12,71 & 0,05 & 5,57 & 1,71 \\
Akhir & & & & & \\
\hline
\end{tabular}

$t_{\text {hitung }}>t_{\text {tabel }}$ maka $H_{1}$ diterima. Berdasarkan data tersebut dapat disimpulkan bahwa terdapat pengaruh penerapan model pembelajaran kooperatif tipe teams games tournament (TGT) terhadap hasil belajar matematika siswa.

Pembelajaran pada kelas eksperimen sesuai dengan tahap pelaksanaan pembelajaran kooperatif tipe Teams Games Tournament (TGT), dimana terbagi atas lima tahap yaitu penyajian kelas, tim, games, tournament, dan penghargaan tim. Menurut Robert E. Slavin Teams Games Tournament terdiri dari lima tahap aktivitas pengajaran, yaitu persiapan, presentasi kelas, belajar kelompok, permainan/pertandingan, dan rekognisi tim.

\section{A. Persiapan}

Guru mempersiapkan media pembelajaran dan materi yang akan disampaikan beserta Lembar Kerja Kelompok (LKK), melakukan tanya jawab mengenai pengetahuan awal materi yang akan dipelajari. Kemudian guru mempersiapkan alat-alat untuk permainan, yaitu: kartu permainan yang dilengkapi nomor, skor, dan pertanyaan mengenai materi.

\section{B. Presentasi Kelas}

Pada awal pembelajaran guru menyampaikan materi dalam penyajian kelas, biasanya dilakukan dengan pengajaran langsung atau dengan ceramah, dan diskusi yang dipimpin guru. Disamping itu, guru juga menyampaikan tujuan, tugas, atau kegiatan yang harus dilakukan siswa, dan memberikan motivasi. Pada saat penyajian kelas ini siswa harus benar-benar memperhatikan dan memahami materi yang disampaikan guru, karena akan membantu siswa bekerja lebih baik pada saat kerja kelompok dan pada saa 
tgame (turnamen) karena skor game akan menentukan skor kelompok.

\section{Belajar Kelompok (Tim)}

Guru membagi siswa dalam kelompokkelompok kecil. Siswa bekerja dalam kelompok yang terdiri atas 5 orang yang anggotanya heterogen dari kemampuan akademik, jenis kelamin, dan ras atau etnik yang berbeda. Dengan adanya heterogenitas anggota kelompok, diharapkan dapat memotivasi siswa untuk saling membantu antar siswa yang berkemampuan lebih dengan siswa yang berkemampuan kurang dalam menguasai materi pelajaran. Hal ini akan menyebabkan tumbuhnya rasa kesadaran pada diri siswa bahwa belajar secara kooperatif sangat menyenangkan.

\section{Permainan/Pertandingan (Game/Turnamen)}

Dalam permainan ini setiap siswa yang bersaing merupakan wakil dari kelompoknya. Siswa yang mewakili kelompoknya, masingmasing ditempatkan dalam meja-meja turnamen. Tiap meja turnamen ditempati 5 sampai 6 orang peserta, dan diusahakan agar tidak ada peserta yang berasal dari kelompok yang sama. Dalam setiap meja turnamen diusahakan setiap peserta mempunyai kemampuan yang homogen.

\section{E. Rekognisi Tim (Penghargaan Tim)}

Langkah pertama sebelum memberikan penghargaan kelompok adalah menghitung rerata skor kelompok. Untuk memilih rerata skor kelompok dilakukan dengan cara menjumlahkan skor yang diperoleh oleh masing-masing anggota kelompok dibagi dengan dibagi dengan banyaknya anggota kelompok. Pemberian penghargaan didasarkan atas rata-rata poin yang didapat oleh kelompok tersebut. Dimana penentuan poin yang diperoleh oleh masing-masing anggota kelompok didasarkan pada jumlah kartu yang diperoleh.

Shoimin (2014) mengukapkan bahwa "Pembelajaran kooperatif tipe Teams Games Tournament (TGT) adalah salah satu tipe atau model pembelajaran kooperatif yang mudah diterapkan, melibatkan aktivitas seluruh siswa tanpa ada perbedaaan status, melibatkan peran siswa sebagai tutor sebaya, dan mengandung unsur seperti permainan dan penghargaan (reinforcement)". Aktivitas belajar siswa dengan model TGT memungkinkan siswa dapat belajar lebih rileks disamping menumbuh-kan tanggung jawab, kerjasama, persaingan sehat, dan keterlibatan belajar.

Pelaksanaan dalam TGT ini adalah pada tahap pertama yaitu tahap penyajian kelas dimana siswa diminta untuk belajar mandiri melalui bahan bacaan yang dimiliki siswa. kemudian siswa diminta untuk bertanya tentang materi yang tidak dipahami siswa.

Pada tahap kedua yaitu tahap kelompok (tim), tiap kelompok beranggotakan 4 sampai dengan 5 orang. Menurut Yasa \& Madio (2014), tujuan dibentuknya suatu kelompok adalah untuk membantu siswa dalam memahami materi bersama teman kelompoknya dan mempersiapkan anggota kelompok agar bekerja dengan baik dan optimal pada saat game (turnamen). Guru membagikan lembar diskusi tim berupa materi dan soal tim yang akan dikerjakan siswa bersama dengan temannya didalam kelompok yang telah dibentuk oleh guru. Dalam kelompok terjadi diskusi untuk memecahkan masalah bersama, saling memberikan jawaban dan mengoreksi jika ada anggota kelompok 


\section{Twebatan slovia 1}

Perhatikanlah bidang koordinat berikut, kemudian jawablah pertanyaan dibawahnya !

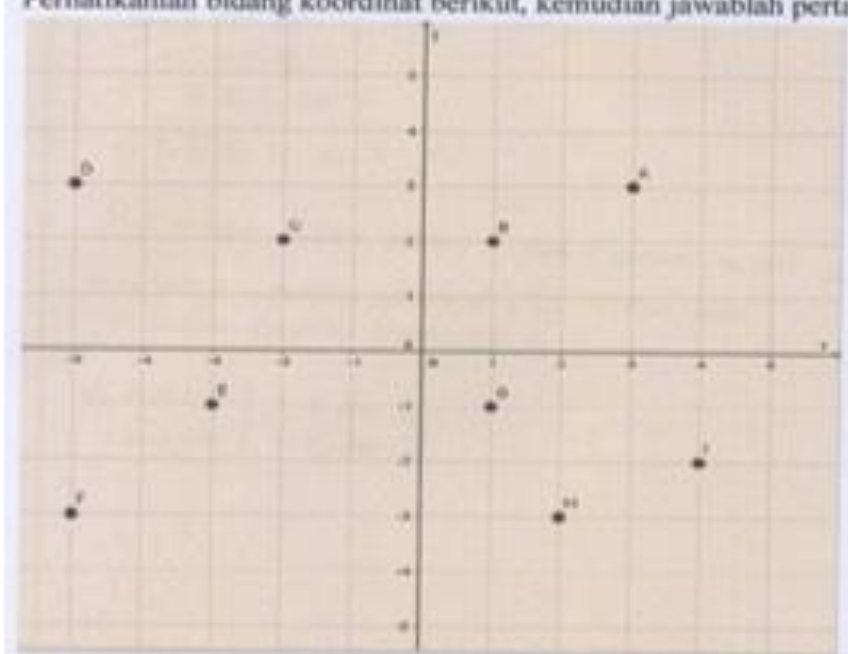

1. Sebotkan titik - titik yang mempunyai jarak yang sama terhadap sumbu $x$

2. Sebutkan titik - titik yang berada dibawah sumbu $x !$

3. Berapa jarak titik $D$, terhadap sumbu $x$ dan sumbu $y$ dan terietak di sebelah mana terhadap sumbu $x$ dan sumbu $y$ ?

4. Sebutkan titik - titik yang jaraknya ke sumbu $x$ dan sumbu $y$ sama dengan titik $G$ !

5. Sebutkan titik - titik yang berada di kuadran I dan III

\section{Gambar 1. Soal Tim [1].}

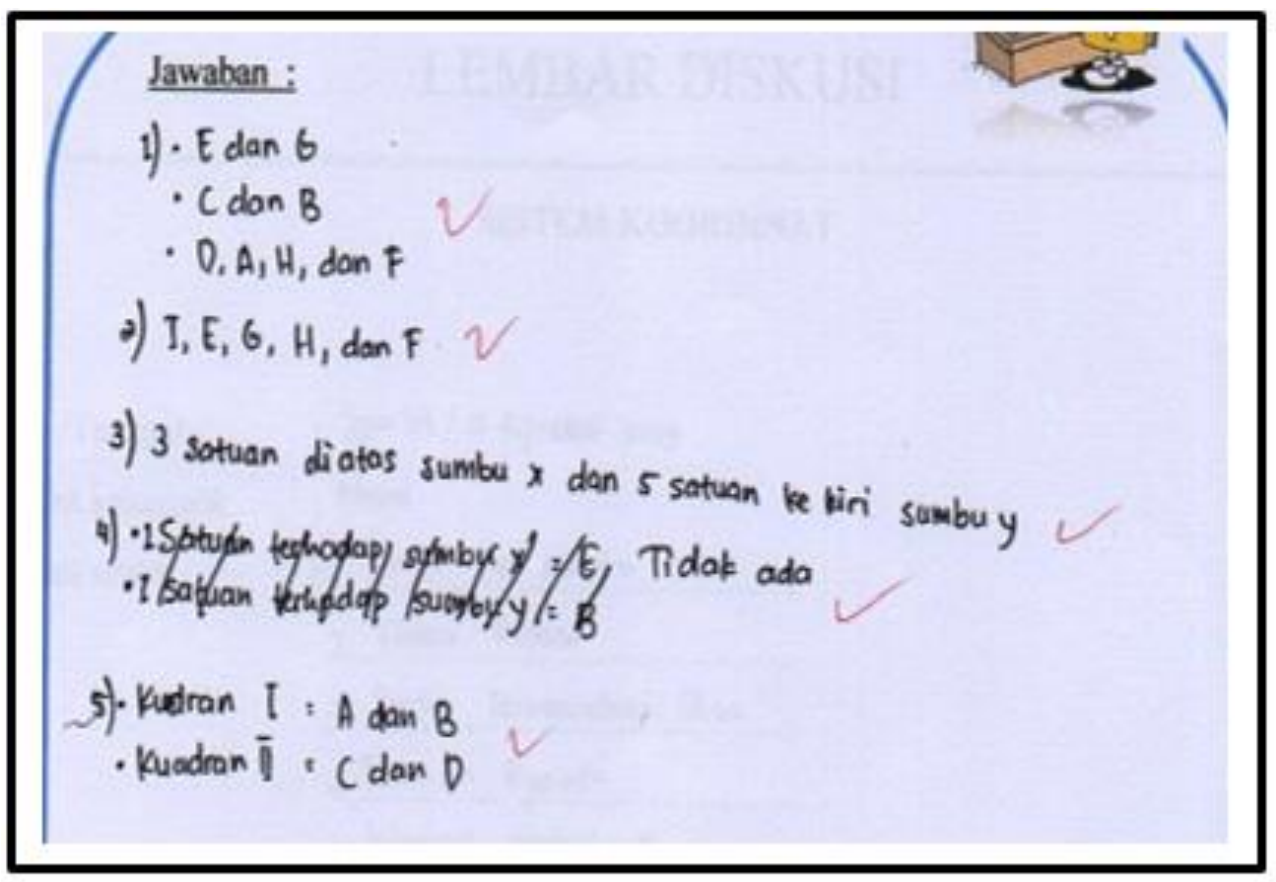

Gambar 2. Jawaban Soal Tim [2].

yang salah dalam menjawab. Berikut adalah contoh soal yang ada pada lembar diskusi tim pada Gambar 1.
Gambar 1 adalah contoh soal yang ada pada lembar diskusi kelompok (tim). Pada saat diskusi siswa sudah mau ikut serta dalam diskusi kelompok. Soal yang ada pada lembar 


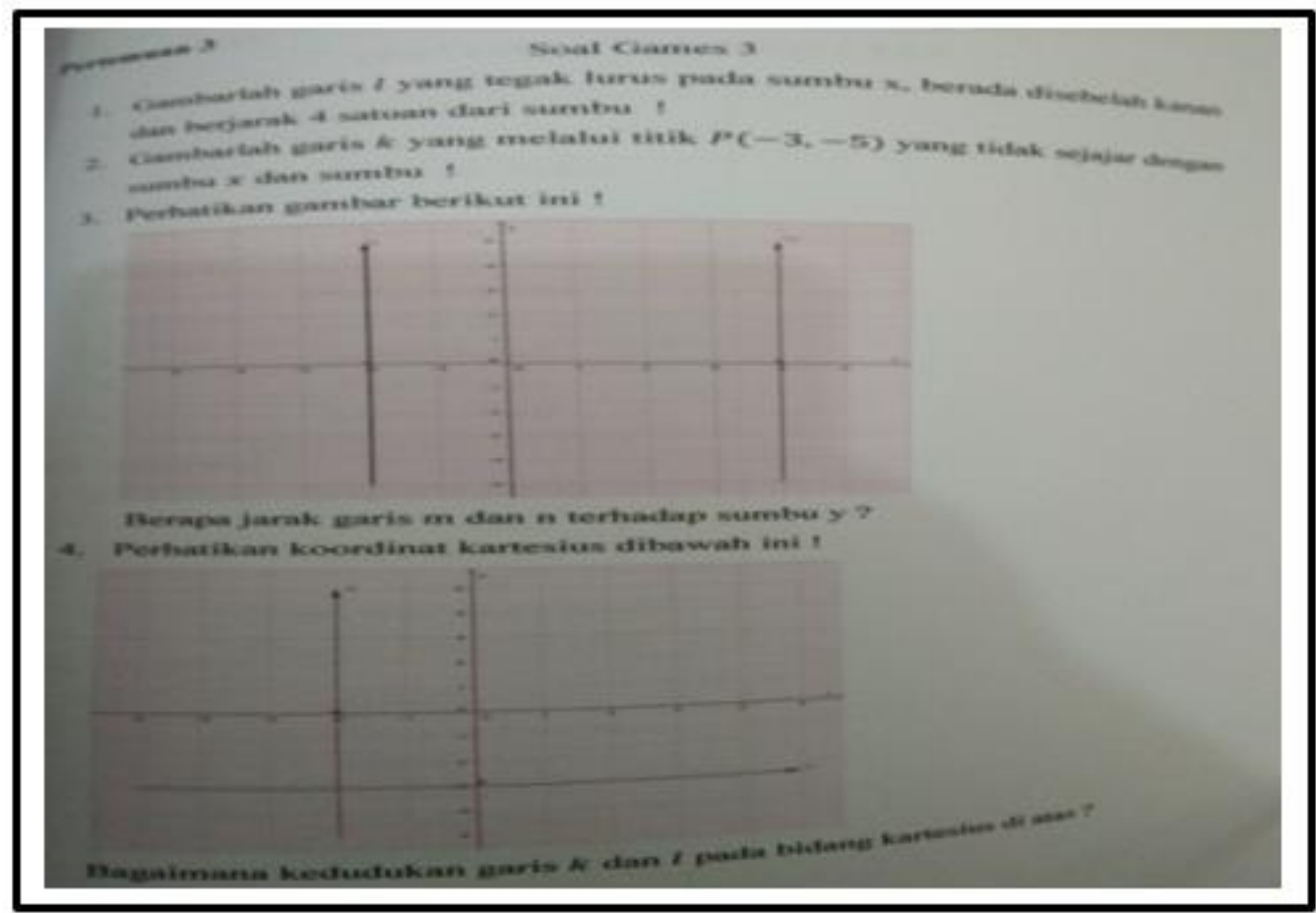

Gambar 3. Soal Game [3].

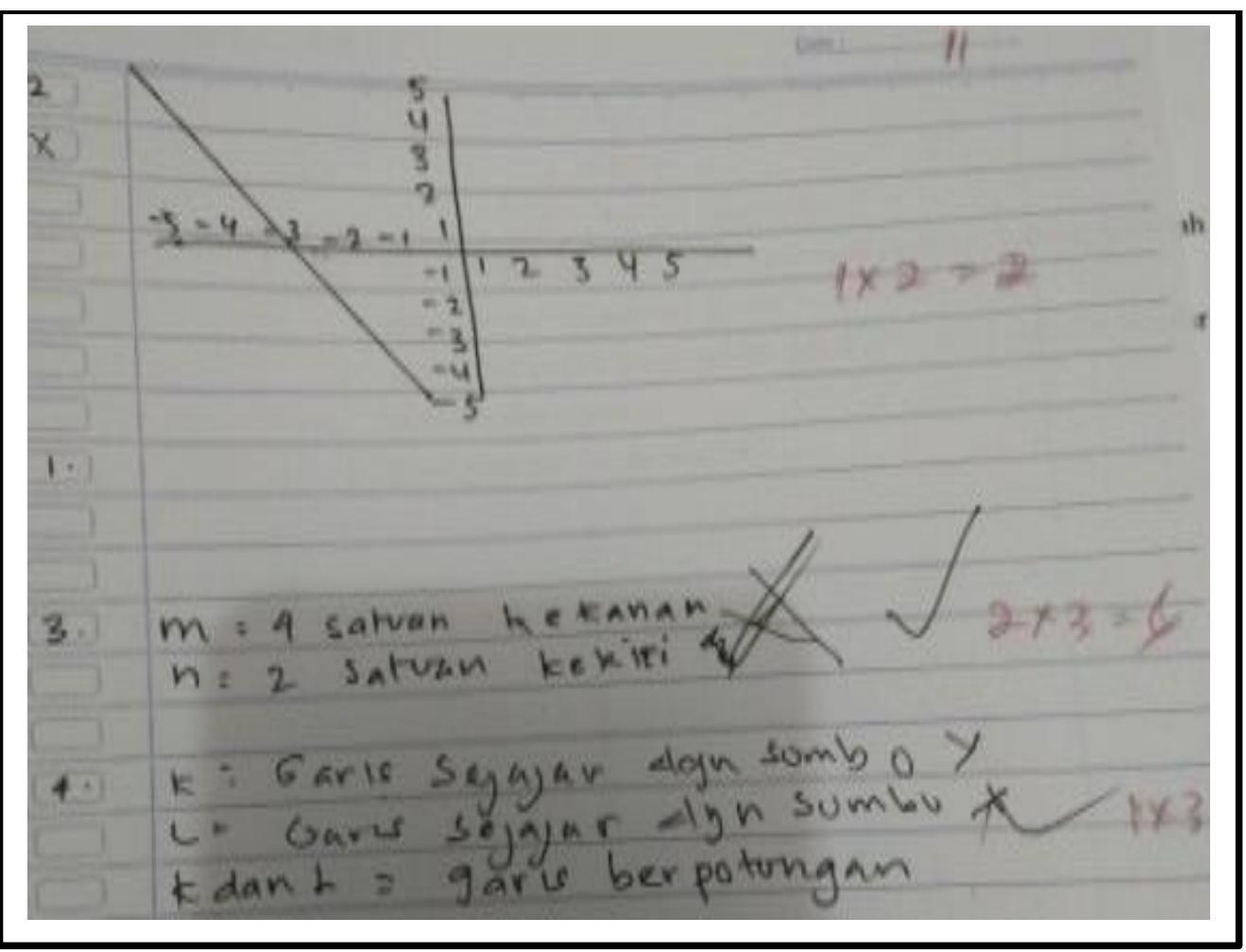

Gambar 4. Jawaban Soal Games [4].

diskusi dikerjakan siswa supaya pada saat games siswa bisa menjawab soal games yang akan diberikan oleh guru.
Gambar 2 adalah hasil jawaban tim yang ada pada lembar diskusi tersebut. Kemudian guru mengajak siswa untuk membahas soal 
yang tidak dipahami siwa bersama didepan papan tulis diwakilkan oleh siswa yang paham tentang soal tersebut dibantu oleh guru.

Pada tahap ketiga yaitu tahap game, guru meminta siswa untuk meduduki meja game yang telah disediakan guru. Siswa yang merupakan peserta game pada meja 1, meja 2, meja 3, dan meja 4 melakukan pencabutan kartu untuk menentukan siapa pembaca pertama dalam pelaksanaan game. Pembaca bertugas membacakan soal yang terpilih oleh pemain dan mengatur jalannya games selama satu putaran soal serta menentukan siapa pemain yang menang dan berhak mendapatkan poin. Berikut contoh soal pada Gambar 3.

Gambar 3 adalah contoh soal game yang dikerjakan masing - masing siswa. Soal games dikerjakan setelah tahap diskusi selesai.

Gambar 4 adalah jawaban salah satu siswa yang mengerjakan soal game.Pada gambar diatas terlihat bahwa siswa sudah mulai paham dengan soal yg dikerjakan.Setelah games selesai dilanjutkan tahap keempat yaitu tahap turnamen. Pada tahap turnamen ini siswa melakukan perpindahan posisi, dimana siswa akan bertukar meja tergantung pada kinerja mereka pada game terakhir. Pemenang dari tiap meja akan naik satu tingkat kemeja berikutnya yang lebih tinggi (misalnya dari meja 2 ke meja 1), skor tertinggi ke 2, 3, dan 4 tetap tinggal pada meja yang sama dan skor yang terendah akan diturunkan.

Tahap terakhir yaitu tahap penghargaan tim. Guru bersama siswa mengitung skor dan poin yang didapat siswa dari pelaksanaan games dan tournament. Penghargaan tim diberikan berdasarkan hasil poin yang didapat kelompok dari rata-rata poin games dan tournament.
Setelah pelaksanaan penelitian yang dilakukan dari 3 pertemuan dilakukan tes akhir untuk mengetahui hasil belajar siswa. Siswa yang mengikuti tes akhir sebanyak 25 siswa. Berikut lembar jawaban tes akhir siswa berkemampuan sedang (lihat gambar 5).

Pada Gambar 5 siswa tersebut hanya menjawab sampai titik $S$ kemudian pada titik Q siswa tesebut melakukan sedikit kesalahan pada pehitungan seharusnya $x_{b}=-1$ dan $y_{b}=7$. Dari hasil tes akhir terlihat siswa mampu menjawab soal tes akhir dikarenakan siswa sudah memahami materi dan siswa juga sudah sering menjawab soal-soal yang berkaitan dengan materi yaitu soal-soal yang diberikan guru pada saat tim, game dan turnamen, sehingga terlihat hasil yang sama dengan penelitian Lisnani (2019), Istiqomah dan Prihatnani (2019), yaitu: peningkatan hasil belajar tes akhir siswa dibandingkan dengan nilai KKM.

Sejalan dengan Susilowati (2014) dan Nurhaeni dan Basuki (2013), strategi pembelajaran Teams Games Tournament (TGT) mampu membuat siswa belajar lebih aktif dan termotivasi dalam memecahkan soal-soal latihan, karena siswa tidak hanya dilibatkan dalam menyelesaikan soal secara berkelompok saja tetapi siswa secara individu juga harus belajar melakukan pekerjaannya sendiri untuk memberikan kontribusi nilai pada kelompoknya. Penerapan metode pembelajaran kooperatif tipe Teams Games Tournament (TGT) sangat sederhana dan mudah untuk diterapkan oleh guru, fleksibel dan tidak membutuhkan guru tambahan ataupun tim guru. Guru hanya perlu menyediakan latihan soal tes untuk game dan tournament serta membagi kelas menjadi lebih menarik dan tidak cepat bosan. Proses pembelajaran ini berpusat pada siswa 


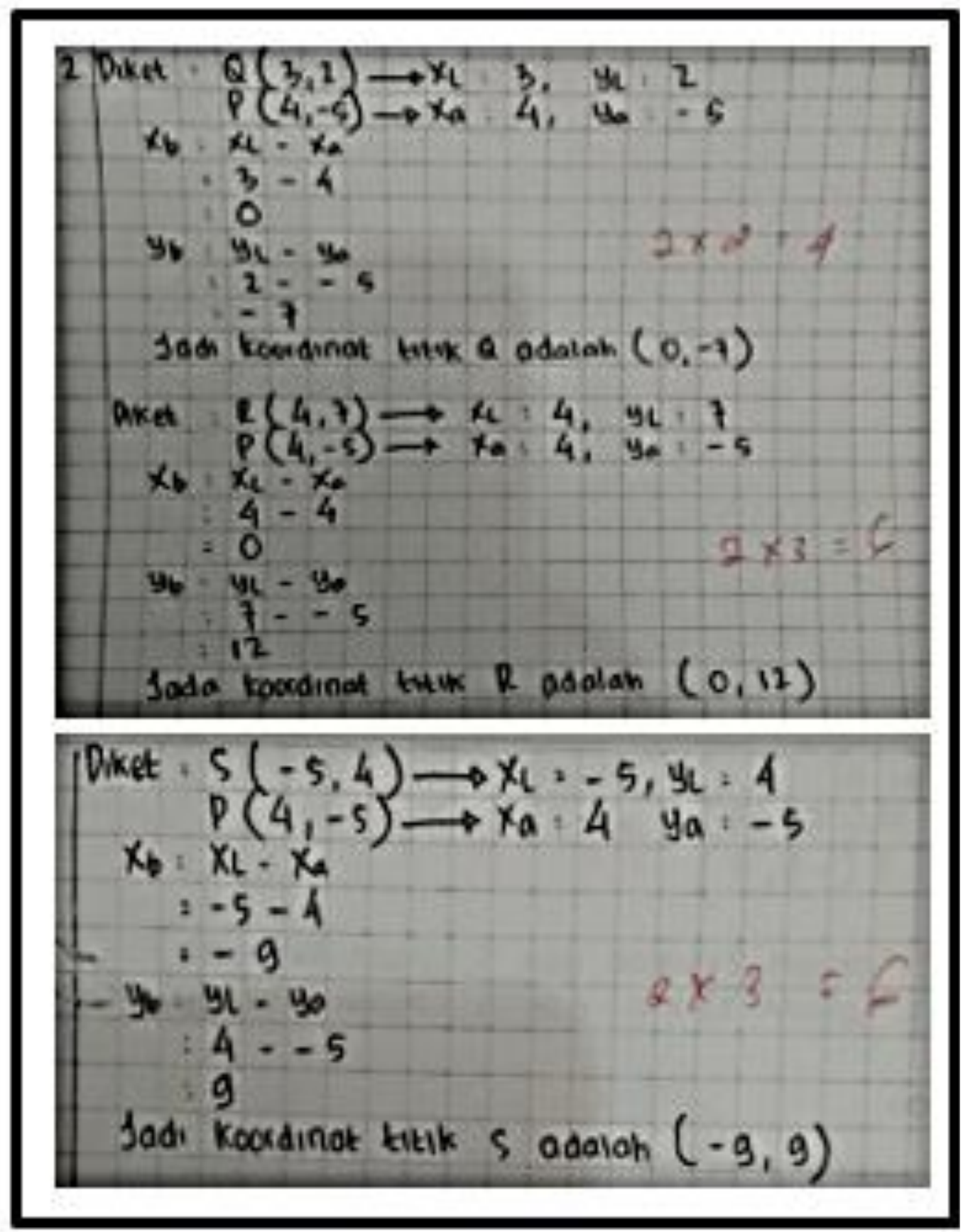

Gambar 5. Lembar Jawaban Tes Akhir [5].

sehingga siswa lebih banyak melakukan aktivitas belajar.

\section{Penutup}

Berdasarkan hasil analisis data dan pembahasan yang telah dikemukakan dapat diambil kesimpulan bahwa terdapat pengaruh model pembelajaran kooperatif tipe Teams
Games Tournament terhadap hasil belajar matematika siswa.

Berdasarkan pembahasan yang telah diuraikan sebelumnya, dapat dikemukakan beberapa saran, diantaranya yaitu diharapkan kepada guru matematika SMPN 5 Padang dapat menerapkan model pembelajaran kooperatif tipe Teams Games Tournament 
sebagai salah satu alternatif dalam melaksanakan proses belajar mengajar. Selain itu, diharapkan kepada peneliti lanjutan untuk menjelaskan alasan pembentukan dan penetapan anggota kelompok kepada siswa, sehingga waktu lebih efektif untuk proses belajar mengajar.

\section{Daftar Pustaka}

Afriansyah, E. A. (2014). What Students' Thinking about Contextual Problems is. International Seminar on Innovation in Mathematics and Mathematics Education.

Afriansyah, E. A. (2016). Makna Realistic dalam RME dan PMRI. LEMMA, 2(2), 96104.

Apiati, V., Heryani, Y., \& Muslim, S. R. (2019). Etnomatematik dalam Bercocok Tanam Padi dan Kerajinan Anyaman Masyarakat Kampung Naga. Mosharafa: Jurnal Pendidikan Matematika, 8(1), 107-118. DOI: https://doi.org/10.31980/mosharafa. v8i1.417

Damayanti, S., \& Apriyanto, M. T. (2017). Pengaruh Model Pembelajaran Kooperatif Tipe Teams Games Tournament Terhadap Hasil Belajar Matematika. JKPM: Jurnal Kajian Pendidikan Matematika, 2(2), 235244.

Firdaus, D. A., \& Afriansyah, E. A. (2016). Pembelajaran Kooperatif Tipe Team Assisted Individually untuk Meningkatkan Kemampuan Pemahaman Matematis Siswa Sekolah Menengah Pertama. Jurnal Pendidikan Matematika RAFA, 2(1), 104122.

Haq, C. N. (2012). Training by Doing. Mosharafa: Jurnal Pendidikan Matematika, 1(1), 43-50.
Istiqomah, U., \& Prihatnani, E. (2019). Peningkatan Hasil Belajar dan Sikap Siswa terhadap Matematika melalui Joyful Learning. Mosharafa: Jurnal Pendidikan Matematika, 8(3), 471-482. DOI: https://doi.org/10.31980/mosharafa. v8i3.470

Jamil. (2013). Strategi Pembelajaran Teori Dan Aplikasi. Jogjakarta: Ar-Ruzz Media

Luritawaty, I. P. (2018). Pembelajaran Take And Give Dalam Upaya Mengembangkan Kemampuan Pemahaman Konsep Matematis. Mosharafa: Jurnal Pendidikan Matematika, $\quad 7(2), \quad$ 179-188. DOI: https://doi.org/10.31980/mosharafa. v7i2.27

Lisnani. (2019). Pengaruh Penggunaan Konteks Daun terhadap Hasil Belajar Siswa. Mosharafa: Jurnal Pendidikan Matematika, 8(3), 423-434. DOI: https://doi.org/10.31980/mosharafa. v8i3.555

Ma'ruf, A. H., Syafii, M., \& Kusuma, A. P. (2019). Pengaruh Model Pembelajaran Mind Mapping Berbasis HOTS terhadap Motivasi dan Hasil Belajar Siswa. Mosharafa: Jurnal Pendidikan Matematika, 8(3), 503-514. DOI: https://doi.org/10.31980/mosharafa. v8i3.552

Melvin, S. (2006). Active Learning. Penerbit Nusa Media. Bandung.

Nurhaeni, K. \& Basuki. (2013). Perbedaan Kemampuan Pemecahan Masalah Matematik Siswa Antara Yang Menggunakan Metode Student Teams Achievement Division Dengan Teams Games Tournament. Mosharafa: Jurnal Pendidikan Matematika, 2(1), 23-36.

Nst, M. N., \& Rahmi. (2017). Pengaruh Penerapan Model Pembelajaran Berbasis 
Masalah Disertai Teknik Berikan Uangnya Terhadap Hasil Belajar Matematika Siswa Kelas Viii Smpn 16 Padang. Mosharafa: Jurnal Pendidikan Matematika, 6(2), 273278.

DOI: https://doi.org/10.31980/mosharafa. $\underline{\mathrm{v} 6 \mathrm{i} 2.315}$

Rayahu, D. V., \& Afriansyah, E. A. (2014). Enhancing the Ability of Mathematics Student Problem Solving through Pembelajaran Pelangi Matematika. International Seminar on Innovation in Mathematics and Mathematics Education 1st ISIM-MED 2014.

Shoimin. (2014). 68 Model Pembelajran Inovatif Dalam Kurikulum 2013. Yogyakarta: Ar-Ruzz Media.

Slavin, R. E. (2005). Cooperative Learning Teori, Riset dan Praktik. Bandung: Penerbit Nusa Media.

Supriatna, R., \& Afriansyah, E. A. (2018). Kemampuan Pemahaman Matematis Peserta Didik melalui Cooperative Learning Tipe Pair Checks VS Problem Based Learning. JPMI (Jurnal Pendidikan Matematika Indonesia), 3(1), 1-6.

Susanna, S. (2018). Penerapan Teams Games Tournament (TGT) Melalui Media Kartu Domino Pada Materi Minyak Bumi Siswa Kelas XI MAN 4 Aceh Besar. Lantanida Journal, 5(2), 93-105

Susilowati, D. (2014). Studi Komparasi Hasil Belajar Akutansi Dengan Penerapan Metode Pembelajaran Teams Games Tournament (TGT) Dengan Metode Ceramah Bervariasi Pada Kompetensi Dasar Jurnal Khusus Siswa Kelas XII IPS SMA Muhammadiyah 01 Pati. Jurnal Pendidikan Ekonomi, 2(3), 9-11.
Widhiastuti, R., \& Fachrurrozie. (2014). Teams Games Tournament (TGT) sebagai Metode untuk Meningkatkan Keaktifan dan Kemampuan Belajar. Jurnal Pendidikan Ekonomi Dinamika Pendidikan, 9(1), 48-56.

Yasa \& Madio, S. S. (2014). Perbedaan Kemampuan Pemecahan Masalah Matematika Antara Kelompok Siswa Yang Mendapatkan Pembelajaran Kooperatif Tipe Teams Games Tournament (TGT) Dengan Student Achievements Divisions (STAD). Mosharafa: Jurnal Pendidikan Matematika, 3(2), 121-131.

Yuhasriati. (2012). Pendekatan Realistik dalam Pembelajaran Matematika. Jurnal Peluang, 1(1), 81-87.

\section{Riwayat Hidup Penulis}

Alfi Yunita, M.Pd.

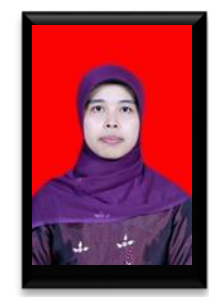

Lahir di padang, 2 Juni 1983, Alumnus SDN 17 Bungo Pasang, SMPN 13 Padang, SMAN 7 Padang, STKIP PGRI Sumatera Barat.

\section{Ratulani Juwita, M.Pd.}

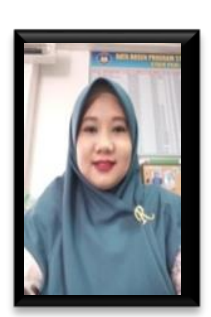

Lahir di Solok, 10 April 1985, Alumnus SDN 35 Panyalai Cupak, SMPN 2 Gunung Talang, Universitas Negeri Padang.

\section{Suci Elma Kartika}

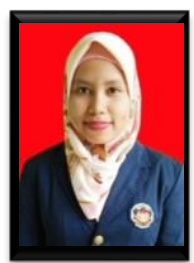

Lahir di Padang, 17 Agustus 1996, Alumnus SDN 1 Tapaktuan, SMPN 1 Tapaktuan, SMAN 1 Tapaktuan Aceh Selatan, STKIP PGRI Sumatera Barat. 


\section{This page is intentionally left blank}

